\title{
LIPOPHILIC AND HYDROPHILIC EXTRACTIVES FROM STRAWBERRY TREE (Arbutus andrachne L.) AND ORIENTAL PLANE (Platanus orientalis L.) WOOD
}

\author{
DÖNMEZ, İ. E. \\ Süleyman Demirel University, Faculty of Forestry, Department of Forest Products Engineering \\ 32100 Isparta, Turkey \\ phone: +90-246-2113968; fax: +90-246-2113948 \\ e-mail: emrahdonmez@sdu.edu.tr \\ (Received 28 ${ }^{\text {th }}$ Sep 2017; accepted 18 $8^{\text {th }}$ Dec 2017)
}

\begin{abstract}
Extractives compose 5-10 \% of wood by weight and they have important roles in trees. Extractive composition of different plant species has to be investigated in order to get the broadest sense. Thus, hexane and acetone:water (95:5, v:v) extracts of Arbutus andrachne and Platanus orientalis wood were analysed by GC-MS and GC-FID to determine lipophilic and hydrophilic extractive composition of these species. Total amount of lipophilic extractives was found 3,39 $\mathrm{mg} / \mathrm{g}$ in A. andrachne wood, whereas it was determined as $16,91 \mathrm{mg} / \mathrm{g}$ in $P$. orientalis wood. However, total amount of hydrophilic extractives in A. andrachne had higher values. Fatty acids were detected as the dominant group in lipophilic extractives in both wood species. Acid 18:3 in A. andrachne wood $(0,17 \mathrm{mg} / \mathrm{g})$ and acid 16:0 in $P$. orientalis wood $(0,19 \mathrm{mg} / \mathrm{g})$ were determined as the highest fatty acids.
\end{abstract}

Keywords: Arbutus andrachne, Platanus orientalis, fatty acids, phenolics, sugars

\section{Introduction}

Plants consist of compounds with high molecular weight such as cellulose, hemicelluloses and lignin. They are essential for survival on organism and called primary metabolites. Primary metabolites compose 90-95 \% of wood by weight. Absence or deficiency of primary metabolites can cause the death of organism. However, extractives are secondary metabolites of plants that affect such functions as texture, odor, taste and color of the tree. Extractives compose 5-10\% of wood chemical substances by weight and they can be classified according to their morphological site in the tree and the function. In addition, extractives can also be determined according to solubility in some solvents and polarity of those solvents (Fengel and Wegener, 1989; Sjöström, 1993; Holmbom, 1999).

In general, extractives can be divided into two sub-groups: lipophilics and hydrophilics. The lipophilic extractives, water-insoluble extractives, in another term, include the substances soluble in neutral solvents such as dichloromethane, diethyl ether and some hydrocarbon solvents. Lipophilic extractives are mainly composed of fats, fatty acids, sterols, and some chemical substances mostly found in softwoods like resin and resin acids (Holmbom, 1999). Hydrophilic extractives are substances that are soluble in such polar solvents as water, alcohol and acetone. Carbohydrates, phenols, lignans and chalkones are some of the hydrophilic extractives (Holmbom, 1999). There are many papers about plant extractives. In last years, studies have been focused on the wood and bark extractives of trees though (Cunha-Queda et al., 2007; Dönmez et al., 2012a; Ekman and Eckerman, 1985; Hafizoğlu, 1982; Hafizoğlu, 1989; Hafizoğlu and Holmbom, 1987; Balaban and Uçar, 2003; Pietarinen et al., 2006; Ferreira et al., 2015), recently, fruit, berry and cone extractives of the trees have been gaining interest (Kilıç et al., 2010a, 2010b, 2011; Dönmez et al., 2012b; Gönültaş and Uçar, 2013). As it is a 
renewable material and the chemicals found in it, tree has important utilization potential in every industrial area.

Analyses of a tree, especially extractives that have minor amount and some sugar compounds like monosaccharides, determines its possible use for other industries (Baptista et al., 2013; Feng et al., 2013). To date, it is known that, extractives can protect wood from decay, add color and odor to wood and enhance the strength properties of wood as well as acting for production of some medicinal products for human health. Thus different kinds of plant species and also different tissues of same species have to be taken into account for more research of chemical composition of trees.

Arbutus andrachne is one of the plant species in Turkey that it is not seen as stand but occurred as soliter along riversides. Moreover it is not utilized in any industrial area except burning its wood in bread producing factories. It is called "sandal" tree in Turkish, but it is officially named as strawberry tree due to its fruits in general. $A$. andrachne is an evergreen tree and has edible fruits that are consumed as jam, jelly and beverage. Fruits of $A$. andrachne have been investigated for their chemical composition because they have rich sugar content. Moreover, protein, ash content and antioxidant properties of $A$. andrachne fruits, extractive composition and suberin monomers of A. andrachne bark were previously presented (Alarcao-E-Silva et al., 2001; Şeker and Toplu, 2010; Serçe et al., 2010; Dönmez et al., 2016). However, any papers about chemical composition of wood of $A$. andrachne is out of our knowledge.

Platanus orientalis is a large deciduous tree and named as oriental plane. It is a natural tree species that is grown around the rivers and used in landscapes and parks (Khan et al., 2013). It is named as "çınar" in Turkish and known as a symbol of long and healthy life. Since it has been growing up in parks in city centers, phenolic composition of its leaves and buds and the effects of environmental stress have been studied but there is limited knowledge of the chemical composition of $P$. orientalis. Most studies on its chemical composition have focused on anticancer or antiseptic properties and activity against urinary infections (Dimas et al., 2000; El-Alfy et al., 2008; Mitrocotsa et al., 1993; Mitrocotsa et al., 1999).

It was aimed to determine the amount and the composition of lipophilic and hydrophilic extractives of $A$. andrachne and $P$. orientalis wood. Thus new data about extractive composition of $A$. andrachne and $P$. orientalis was presented to the literature.

\section{Material and Method}

A. andrachne and $P$. orientalis samples were taken from the altitude of $375 \mathrm{~m}$. from Aşağıgökdere-Eğirdir, Isparta, Turkey. Diameters of the trees were $27 \mathrm{~cm}$. and $29 \mathrm{~cm}$. for $A$. andrachne and $P$. orientalis respectively. Samples were taken according to TAPPI-T-257 cm-02 standard. Debarked samples were stored at $-24{ }^{\circ} \mathrm{C}$ until analyses. All of the samples were freeze-dried and grounded by Wiley mill to $1 \mathrm{~mm}$ (Ekman, 1983). To prevent the effect of volatile compounds, a second drying procedure was treated to the grounded samples.

\section{Extraction}

Approximately $5 \mathrm{~g}$ of grounded wood from each sample was sequentially extracted with an accelerated solvent extractor (ASE) apparatus (ASE 200, Dionex Inc., Sunnyvale, CA, USA). Samples were successively extracted with n-hexane, 
acetone:water (95:5, v:v), and finally distilled water. After extraction, aliquots of extractives were completed to $100 \mathrm{ml}$ with the same solvent used in extraction so gravimetric analyses were carried out. For gravimetric analyses, $10 \mathrm{ml}$ of the aliquot was evaporated to dryness, i.e, constant weight, leaving a film of extractives in the solvent container. The containers were weighed before and after extraction to determine the extractive yield in $\mathrm{mg} / \mathrm{g}$. An internal standard (heneicosanoic acid and betulinol) was added to the hexane and acetone:water (95:5, v:v) extracts. The mixture was evaporated under nitrogen prior to silylation. Hexane and acetone:water (95:5, v:v) extracts were injected to GC-MS and GC-FID for identifying lipophilics and hydrophilics.

\section{Identification}

Quantitative analyses of both extractives from the wood of A. andrachne and P. orientalis were performed with a Pelkin Elmer Autosystem XL gas chromatograph (GCFID; PerkinElmer Inc., Waltham, MA, USA) equipped with an HP-1 $25 \mathrm{~m} \times 0.2 \mathrm{~mm}$ $\left(0.11 \mu \mathrm{m}\right.$ film thickness) column and flame ionization detector. The carrier gas was $\mathrm{H}_{2}$ added at $0.8 \mathrm{~mL} / \mathrm{min}$. The temperature program began at $120{ }^{\circ} \mathrm{C}$, which was raised by steps of $6{ }^{\circ} \mathrm{C} / \mathrm{min}$ to $320{ }^{\circ} \mathrm{C}$. The injector temperature was $260{ }^{\circ} \mathrm{C}$, and the FID temperature was $320{ }^{\circ} \mathrm{C}$. One $\mu \mathrm{L}$ of each sample was injected (split ratio: 1:24). Individual compounds were identified with an HP 6890-5973 gas chromatography/mass spectrometry (GC-MS) instrument (Agilent Technologies Inc., Santa Clara, CA, USA) equipped with an HP-1 column. The temperature program was the same as above.

\section{Results and Discussions}

Lipophilic and hydrophilic components of $A$. andrachne and $P$. orientalis wood were analysed by GC-MS and GC-FID after extraction with different solvents. The amount of soluble substances in the solvents and water was determined gravimetrically and shown in Figure 1.

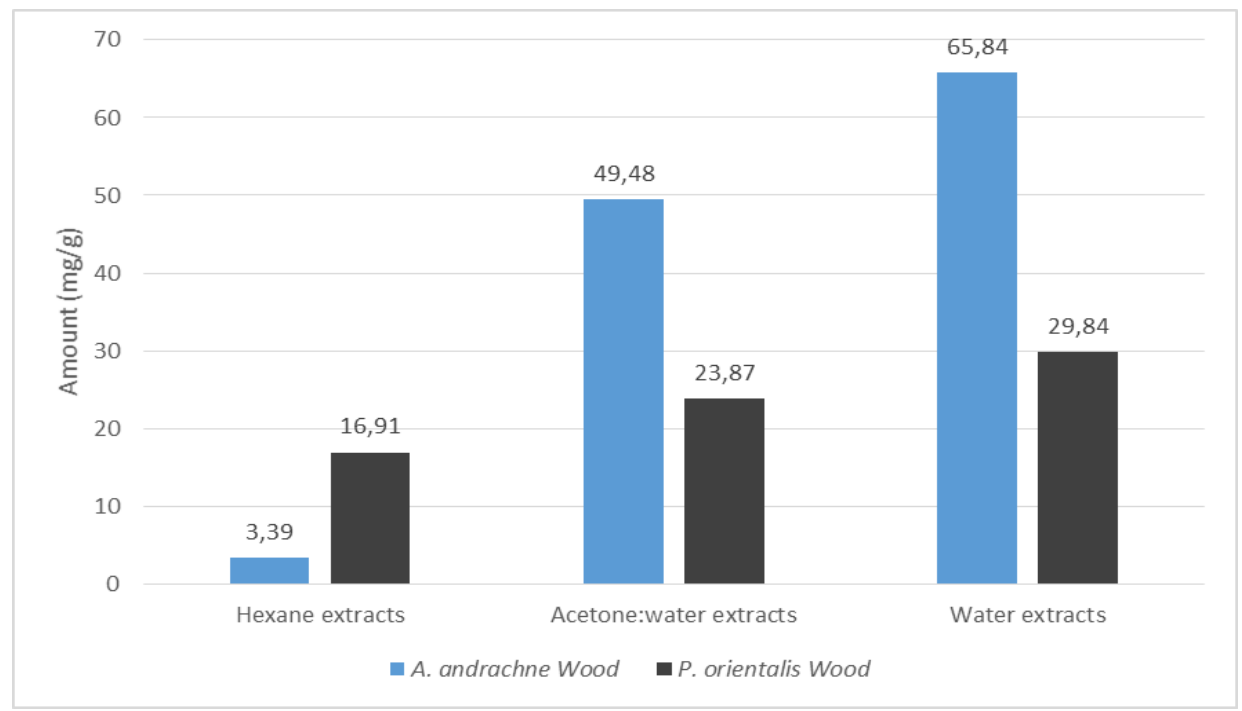

Figure 1. Gravimetric amount of extractives from A. andrachne and P. orientalis wood ( $m g / g$ of dry weight) 
Gravimetric analyses results of $A$. andrachne wood were found higher than $P$. orientalis wood results. It was also observed in our previous study that bark samples of both species had the same results for gravimetric analyses (Dönmez et al., 2016). Acetone:water (95:5, v:v) and water solubility in A. andrachne wood was seen twotimes more comparing to $P$. orientalis wood. While acetone:water $(95: 5, \mathrm{v}: \mathrm{v})$ was determined as $49,48 \mathrm{mg} / \mathrm{g}$ in A. andrachne wood, it was found as $23,87 \mathrm{mg} / \mathrm{g}$ in P. orientalis wood. Hot water solubility in A. andrachne wood was determined as 65,84 $\mathrm{mg} / \mathrm{g}$ though, it was identified as $29,84 \mathrm{mg} / \mathrm{g}$ in $P$. orientalis wood. It is known that fruits and bark of A. andrachne have rich sugar content (Serçe et al., 2010; Şeker and Toplu, 2010; Dönmez et al., 2016). Moreover, this work shows that wood of A. andrachne is rich in its sugar content. Contrary to this results, only P. orientalis wood hexane solubility $(16,91 \mathrm{mg} / \mathrm{g})$ was found higher than A. andrachne wood hexane solubility $(3,39 \mathrm{mg} / \mathrm{g})$.

Hexane and acetone:water (95:5, v:v) extracts were firstly injected to GC-MS for qualitative identification, secondly to GC-FID for quantative determination just after suitable amounts of mixture of solvent and extracts was determined for chromatographic analyses. Extractive composition and the amount can be seen in Table 1.

Table 1. Extractive composition of A. andrachne and P. orientalis wood ( $\mathrm{mg} / \mathrm{g}$ of dry weight)

Fatty Acids

Acid 16:0

Acid 18:3

Acid 18:1

Acid 18:0

Acid 18:2

Sugars

D-xylose

D-fructose

Sorbopyranose

$\alpha$-d-glucopyranose

Pinitol + D-glucose

L-rhamnose

Mannose

Sucrose

Myo-inositol

Unidentified sugar compounds

Maltitol

Phenolics

3,4-dihydroxybenzoic acid

Catechin

Phytosterol

Sitosterol

Other

Hydroquinone-beta d glucopyranoside

Betulinic acid

Sinapyl alcohol

Lupeol

\section{A. andrachne P. orientalis}

$\begin{array}{ll}0.05 & 0.19 \\ 0.17 & 0.08 \\ 0.02 & 0.08 \\ 0.09 & 0.10 \\ 0.05 & 0.09\end{array}$

0.03

0.03

0.29

0.22

1.15

0.46

$0.07 \quad 0.03$

$\begin{array}{ll}1.39 & 4.61\end{array}$

$0.03 \quad 0.10$

$0.02 \quad 0.04$

$0.48 \quad 0.04$

$0.14 \quad 0.08$

$4.36 \quad 1.91$

$0.02 \quad 0.04$

$\begin{array}{ll}0.01 & 0.03\end{array}$

$3.74 \quad 1.46$

$\begin{array}{ll}0.17 & 0.15\end{array}$

$0.01 \quad 0.08$

$0.01 \quad 0.98$

$0.08 \quad 0.08$

$\begin{array}{ll}0.02 & 0.01\end{array}$ 
5 different fatty acids were detected in both samples. While acid 16:0 was determined as the highest amount in P. orientalis wood $(0.19 \mathrm{mg} / \mathrm{g})$, acid $18: 3$ was seen as the dominant fatty acid in A. andrachne wood $(0.17 \mathrm{mg} / \mathrm{g})$.

$\beta$-sitosterol was found as the only phytosterol in the sterols group that was the second lipophilic substances group after fatty acids detected in samples. It was found both in $A$. andrachne $(0.17 \mathrm{mg} / \mathrm{g})$ and in $P$. orientalis $(0.15 \mathrm{mg} / \mathrm{g})$ wood.

The compounds in sugar group, a hydrophilic group, was determined by injecting of acetone:water (95:5, v:v) extracts. Total amount of sugar group was found as 7,98 $\mathrm{mg} / \mathrm{g}$ and $7,56 \mathrm{mg} / \mathrm{g}$ in $A$. andrachne and $P$. orientalis wood respectively. There are not any research on the literature about extractive structure of $A$. andrachne and $P$. orientalis wood. However, chemical composition of bark of same trees was reported by Dönmez et al. (2016). It was seen that total amount of sugar group in wood was lower than their bark.

Phenolics were the other hydrophilic group and only two components (3,4dihydroxybenzoic acid and catechin) were detected in both samples. Catechin was seen as the dominant component and had the highest proportion in both A. andrachne $(3,74$ $\mathrm{mg} / \mathrm{g}$ ) and $P$. orientalis $(1,46 \mathrm{mg} / \mathrm{g})$ wood.

Besides, hydroquinone- $\beta$-d glucopyranoside, a glycoside, betulinic acid, a triterpenic acid, and sinapyl alcohol, an organic compound, were also determined in all samples.

\section{Conclusions}

Hexane, acetone:water (95:5, v:v) extracts of A. andrachne and $P$. orientalis after successive extraction were analysed by GC-MS and GC-FID to obtain lipophilic and hydrophilic extractives. Total amount of lipophilic extractives was lower $(3,39 \mathrm{mg} / \mathrm{g})$ in $A$. andrachne wood than $P$. orientalis wood $(16,91 \mathrm{mg} / \mathrm{g})$. However, hydrophilic extractives was found two-times more in A. andrachne wood $(49,48 \mathrm{mg} / \mathrm{g})$ than $P$. orientalis wood $(23,87 \mathrm{mg} / \mathrm{g})$. Fatty acids were the dominant lipophilic extractive group in both wood species. While acid 18:3 in A. andrachne wood was detected as the most abundant compound, acid 16:0 had the highest amount in P. orientalis wood. Sugars were seen as the main hydrophilic extractive group both in $A$. andrachne and in $P$. orientalis wood. It is seen that wood of the both species have same extractive composition with their bark but the amount of wood extractives is lower comparing to their bark (Dönmez et al., 2016).

Acknowledgements. The author thank to Prof. Dr. Stefan Willför, Dr. Annika Smeds and Jarl Hemming, Laboratory of Wood and Paper Chemistry, Åbo Akademi University, Turku, Finland, for their support and discussions.

\section{REFERENCES}

[1] Alarcao-E-Silva, M.L.C.M.M., Leitao, A.E.B., Azinheira, H.G., Leitao, M.C.A. (2001): The Arbutus berry: studies on its color and chemical characteristics at two mature stages.-Journal of Food Composition and Analysis 14: 27-35.

[2] Balaban, M., Uçar, G. (2003): Estimation of volatile acids in wood and bark.-Holz als Roh und Werkstoff 61: 465-468.

[3] Baptista, I., Miranda, I., Quilhó, T., Gominho, J., Pereira, H. (2013): Characterisation and fractioning of Tectona grandis bark in view of its valorisation as a biorefinery rawmaterial.-Industrial Crops and Products 50: 166-175. 
[4] Cunha-Queda, A.C., Riberira, H.M., Ramos, A., Cabral, F. (2007): Study of biochemical and microbiological parameters during composting of pine and eucalyptus bark.Bioresource Technology 98: 3213-3220.

[5] Dimas, K., Demetzos, C., Mitaku, S., Marselos, M., Tzavaras, T., Kokkinopoulos, D. (2000): Cytotoxic activity of kaempferol glycosides against human leukaemic cell lines in vitro.-Pharmacological Research 41: 83-86.

[6] Dönmez, I.E., Hafizoğlu, H., Kilic, A., Tümen, I., Sivrikaya, H. (2012a): Chemical composition of fourteen different coniferous species cones growing naturally in Turkey.Wood Research 57: 339-344.

[7] Dönmez, I.E., Hafizoğlu, H., Kılıç, A., Hemming, J., Eckerman, C. (2012b): Effect of altitude on the composition of suberin monomers in the outer bark of Scots pine (Pinus sylvestris L.).- Industrial Crops and Products 37: 441-444.

[8] Dönmez, İ.E., Hemming, J., Willför, S. (2016): Bark extractives and suberin monomers from Arbutus andrachne and Platanus orientalis.-BioResources 11: 2809-2819.

[9] Ekman, R. (1983): The suberin monomers and triterpenoids from the outer bark of Betula verrucosa Ehrh.-Holzforschung 37: 205-211.

[10] Ekman, R., Eckerman, C. (1985): Aliphatic carboxylic acids from suberin in birch outer bark by hydrolysis, methanolysis and alkali fusion.-Paperi ja puu 67: 255-273.

[11] El-Alfy, T.S., El-Gohary, H., Sokkar, N.M., Sleem, A.A., Al-Mahdy, D.A. (2008): Phenolic constituents of Platanus orientalis L. leaves.-Natural Product Communications 3: $1-5$.

[12] Feng, S., Cheng, S., Yuan, Z., Leitch, M., Xu, C.C. (2013): Valorization of bark for chemicals and materials: a review.-Renewable Sustainable Energy Reviews. 26: 560578.

[13] Fengel, D., Wegener, G. (1989): Wood Chemistry.-Ultrastructure, Reactions, Walter de Gruyter, Berlin.

[14] Ferreira, J.P.A., Miranda, I., Gominho, J., Pereira, H. (2015): Selective fractioning of Pseudotsuga menziesii bark in view of an integrated valorization-Industrial Crops and Products 74: 998-1007.

[15] Gonultas, O., Ucar, M.B. (2013): Chemical characteristics of the cone and wood of Pinus pinea-Lignocellulose 2: 262-269.

[16] Hafizoğlu, H. (1982): Orman Ürünleri Kimyası--Odun Kimyası, K.T.Ü. Orman Fakültesi Yayını, Trabzon.

[17] Hafizoğlu, H. (1989): Studies on the wood and bark constituents of Pinus pinea L.Holzforschung 43: 41-43.

[18] Hafizoğlu, H., Holmbom, B. (1987): Studies on the chemistry of Cedrus libani A. Rich. II. Lipophilic constituents of the cedar bark.-Holzforschung 41: 273-277.

[19] Holmbom, B. (1999): Extractives in: Analytical Methods in Wood Chemistry, Pulping, and Papermaking, Sjöström, E., and Alén, R. (eds.), Springer-Verlag, Berlin.

[20] Khan, I., Sangwan, P.L., Dar, A.A., Rafiq, R.A., Farrukh, M.R., Dhar, J.K., Tasduq, S.A., Koul, S. (2013): A validated high-performance thin-layer chromatography method for the identification and simultaneous quantification of six markers from Platanus orientalis and their cytotoxic profiles against skin cancer cell lines.-Journal of Separation Science 36: 2602-2610.

[21] Kilic, A., Hafizoglu, H., Tümen, I., Dönmez, I.E., Sivrikaya, H., Hemming, J. (2010a): Phenolic extractives of cones and berries from Turkish coniferous species.-European Journal of Wood and Wood Products 69: 63-66.

[22] Kilic, A., Hafizoglu, H., Tümen, I., Dönmez, I.E., Sivrikaya, H., Sundberg, A., Holmbom, B. (2010b): Polysaccharides in cones of eleven coniferous species growing in Turkey.- Wood Science and Technology 44: 523-529.

[23] Kilic, A., Hafizoglu, H., Dönmez, I.E., Tümen, I., Sivrikaya, H., Reunanen, M., Hemming, J. (2011): Extractives in the cones of Pinus species. European Journal of Wood and Wood Products 69: 37-40. 
[24] Mitrocotsa, D., Bosch, S., Mitaku, S., Dimas, C., Skaltsounis, A.L., Harval, C., Briand, G., Roussakis, C. (1999): Cytotoxicity against human leukemic cell lines, and the activity on the expression of resistance genes of flavonoids from Platanus orientalis.-Anticancer Research Journal 19: 2085-2088.

[25] Mitrocotsa, D., Mitaku, S., Demetzos, C., Harvala, C., Mentis, A., Perez, S., Kokkinopoulos, D. (1993): Bioactive compounds from the buds of Platanus orientalis and isolation of a new kaempferol glycoside.-Planta Medica 59(6): 517-520.

[26] Pietarinen, S.P., Wilför, S.M., Athotupa, M.O., Hemming, J.E., Holmbom, B.R. (2006): Knotwoods and bark extracts: Strong antioxidants from waste materials.-Journal of Wood Science 52: 436-444.

[27] Serçe, S., Özgen, M., Torun, A.A., Ercişli, S. (2010): Chemical composition, antioxidant activities, and total phenolic content of Arbutus andrachne L. (Fam. Ericaceae) (the Greek strawberry tree) fruits from Turkey.-Journal of Food Composition and Analysis 23:619-623.

[28] Sjöström, E. (1993): Wood Chemistry Fundamentals and Applications (2nd Edition), Academic Press, San Diego.

[29] Şeker, M., Toplu, C. (2010). "Determination and comparison of chemical characteristics of Arbutus unedo L. and Arbutus andrachne L. (Family Ericaceae) fruits. - Journal of Medicinal Food 13(4): 1013-1018. 